\title{
Maximization of Astaxanthin Production from Green Microalga Haematococcus pluvialis Using Internally-Illuminated Photobioreactor
}

\author{
Yiu Hang $\mathrm{Ho}^{3}$, Ho Man Leung ${ }^{4}$, Shuk Ying Yuen ${ }^{3}$, Kei Shing $\mathrm{Ng}^{3}$, Tak Sing Li ${ }^{1,2,3}$, Lap Ming Yuen ${ }^{3}$, \\ Yee Keung Wong ${ }^{1,2,3, *}$
}

${ }^{1}$ Institute for Research in Innovative Technology \& Sustainability (IRITS), the Open University of Hong Kong, HKSAR, China

${ }^{2}$ Centre for Excellence in Water Quality and Algal Research, the Open University of Hong Kong, HKSAR, China

${ }^{3}$ School of Science and Technology, the Open University of Hong Kong, HKSAR, China

${ }^{4}$ Department of Biology, Hong Kong Baptist University, HKSAR, China

\section{Email address:}

msn_tommy@hotmail.com (Yiu Hang Ho), leungmh@gmail.com (Ho Man Leung), coralyuen001@gmail.com (Shuk Ying Yuen), dng@ouhk.edu.hk (Kei Shing Ng), tsli@ouhk.edu.hk (Tak Sing Li), lmyuen@ouhk.edu.hk (Lap Ming Yuen),

yekwong@ouhk.edu.hk (Yee Keung Wong)

${ }^{*}$ Corresponding author

\section{To cite this article:}

Yiu Hang Ho, Ho Man Leung, Shuk Ying Yuen, Kei Shing Ng, Tak Sing Li, Lap Ming Yuen, Yee Keung Wong. Maximization of Astaxanthin Production from Green Microalga Haematococcus pluvialis Using Internally-Illuminated Photobioreactor. Advances in Bioscience and Bioengineering. Vol. 6, No. 2, 2018, pp. 10-22. doi: 10.11648/j.abb.20180602.11

Received: May 31, 2018; Accepted: June 8, 2018; Published: July 14, 2018

\begin{abstract}
An internally-illuminated photobioreactor was designed to maximize the astaxanthin production by Haematococcus pluvialis. Four optimization steps were conducted: 1. light wavelength 2 . light intensity 3 . astaxanthin formation and 4. astaxanthin extraction methods. Efficient biomass production of $H$. pluvialis of $4.58 \pm 0.15 \times 10^{5}$ cells $/ \mathrm{ml}$ and dry biomass of $520 \pm 12.5 \mathrm{mg} / \mathrm{L}$ was accomplished under red LED light $(660 \mathrm{~nm})$ with $70 \mu \mathrm{mol} \mathrm{m}^{-2} \mathrm{~s}^{-1}$. Besides, the biomass production can be optimized to $5.31 \pm 0.15 \times 10^{5} \mathrm{cells} / \mathrm{ml}$ and dry biomass of $680 \pm 10.5 \mathrm{mg} / \mathrm{L}$ under $140 \mu \mathrm{mol} \mathrm{m}^{-2} \mathrm{~s}^{-1}$ in the light intensity of 70-210 $\mu \mathrm{mol} \mathrm{m}^{-2} \mathrm{~s}^{-1}$. Furthermore, the astaxanthin accumulation was significant with 7 days encystment under $140 \mu \mathrm{mol} \mathrm{m} \mathrm{m}^{-1}$ blue LED lights. For extraction method, using hydrochloric acid could obtain the highest astaxanthin yield of $3.85 \pm 0.05 \%$ (\% to dry weight). Further studies were proposed whatever such photobioreactor can be applied to different microalgal strains.
\end{abstract}

Keywords: Astaxanthin, Haematococcus Pluvialis, Internally-Illuminated Photobioreactor, Lighting, Cell Disruption, Extractability

\section{Introduction}

Currently, research findings mentioned that the green microalga Haematococcus pluvialis (H. pluvialis) was recognized in synthesizing and accumulating the largest amount of natural astaxanthin [1-5]. When microalgae expose to an oxidative stress environment, the overproduction of reactive oxygen species and singlet oxygen leads to poor cell growth and molecule damage, such as DNA, lipid and protein [6-10]. Astaxanthin production is a cell protective mechanism against long-term oxidative stress in the encysted stage of $H$. pluvialis [4]. The major function of astaxanthin is the neutralizing effect against singlet oxygen and exhibits a powerful scavenging ability for free radicals [11]. Due to its powerful antioxidative ability, astaxanthin is applied as a nutraceutical and pharmaceutical agent in commercial applications, for treating diseases, such as cardiovascular diseases such as atherosclerosis, degenerative diseases such as metabolic syndrome and eye diseases such as cataract $[12,13]$. It is also applied to feed supplements for salmon and rainbow trout as a food coloring agent $[14,15]$. The astaxanthin pigment imparted in the fish 
bodies can enhance their immunity and reproduction capacity $[8,16-18]$.

Some recent findings exhibited that natural astaxanthin extracted from $H$. pluvialis is fifty and twenty times stronger than synthetic astaxanthin regarding singlet oxygen quenching and free radical elimination, respectively $[19,20]$. Under oxidative stress, $H$. pluvialis transforms from the green motile stage into the red non-motile resting stage with increasing amount of astaxanthin (brown cells). The "brown" cells are more tolerant to the oxidative stresses. The "red" cells, finally accompanied with high astaxanthin content for protecting the cells from photooxidative stress, survive in the adverse environment [21]. In previous studies, artificial stress conditions were applied, such as nutrient deprivation (e.g., nitrogen and phosphorous). Excess photosynthetic photon flux density, salt and metal ions stress, either used singly or simultaneously, can accelerate the synthesis and accumulation of astaxanthin but the yield of product is controversial $[1,7,22,23]$.

It is inevitable that photoinhibition and photooxidation effects happened during microalgal cultivation [24]. In this research, an internally illuminated photobioreactor with LEDs light was installed to minimize the contamination with cultivation period and provide adjustable light conditions (light-dark cycle, light wavelength and light intensity) for the two-stage cultivation of $H$. pluvialis $[25,26]$. Thus, optimized conditions in photobioreactor and suitable extraction method are crucial to the biomass productivity and astaxanthin synthetic rate. Therefore, this work aimed to maximize the production of astaxanthin in H. pluvialis.

\section{Materials and Methods}

\subsection{Microalgal Strain and Chemicals}

H. pluvialis Flotow (UTEX 2505) was obtained from the algal culture collection at the University of Texas, Austin, Texas, USA and maintained in Bold Basal Medium (BBM) composed of $\mathrm{NaNO}_{3} 0.25 \mathrm{~g}, \quad \mathrm{CaCl}_{2} \cdot 2 \mathrm{H}_{2} \mathrm{O} \quad 0.025 \mathrm{~g}$, $\mathrm{MgSO}_{4} \cdot 7 \mathrm{H}_{2} \mathrm{O} 0.075 \mathrm{~g}, \mathrm{~K}_{2} \mathrm{HPO}_{4} 0.075 \mathrm{~g}, \mathrm{KH}_{2} \mathrm{PO} 40.175 \mathrm{~g}$, $\mathrm{NaCl} 0.025$ g, EDTA 0.05 g, KOH 0.031 g, $\mathrm{FeSO}_{4} \cdot 7 \mathrm{H}_{2} \mathrm{O}$ $4.98 \mathrm{mg}, \mathrm{H}_{3} \mathrm{BO}_{3} 11.42 \mathrm{mg}, \quad \mathrm{ZnSO}_{4} \cdot 7 \mathrm{H}_{2} \mathrm{O} 8.82 \mathrm{mg}$, $\mathrm{MnCl}_{2} \cdot 4 \mathrm{H}_{2} \mathrm{O} 1.44 \mathrm{mg}, \mathrm{MoO}_{3} 0.71 \mathrm{mg}, \mathrm{CuSO}_{4} \cdot 5 \mathrm{H}_{2} \mathrm{O} 1.57$ $\mathrm{mg}$, Co $(\mathrm{NO} 3)_{2} \cdot 6 \mathrm{H}_{2} \mathrm{O} 0.49 \mathrm{mg}$ per one liter of deionized distilled water [27]. For the seed culture, $100 \mathrm{ml}$ algal culture with $250 \mathrm{ml}$ of BBM was used for cultivation. The sterilized air was continuously bubbled into the culture in Erlenmeyer flask through an air pump (V-30, Hailea, China) as a source of $\mathrm{CO}_{2}$ and syringe filter (DISMIC-250CS, $0.45 \mu \mathrm{m}$, ADVANTEC, Japan). The lighting was supplied by cool white fluorescent tubes in a growth chamber (MLR-352-PE, Panasonic, Japan) with $50 \mu \mathrm{mol} \mathrm{m} \mathrm{m}^{-2} \mathrm{~s}^{-1}$ in a light/dark cycle of $12: 12 \mathrm{~h}$ under $20 \pm 1^{\circ} \mathrm{C}$. Subcultures of the algal cells were made weekly.

\subsection{Photobioreactor Setup}

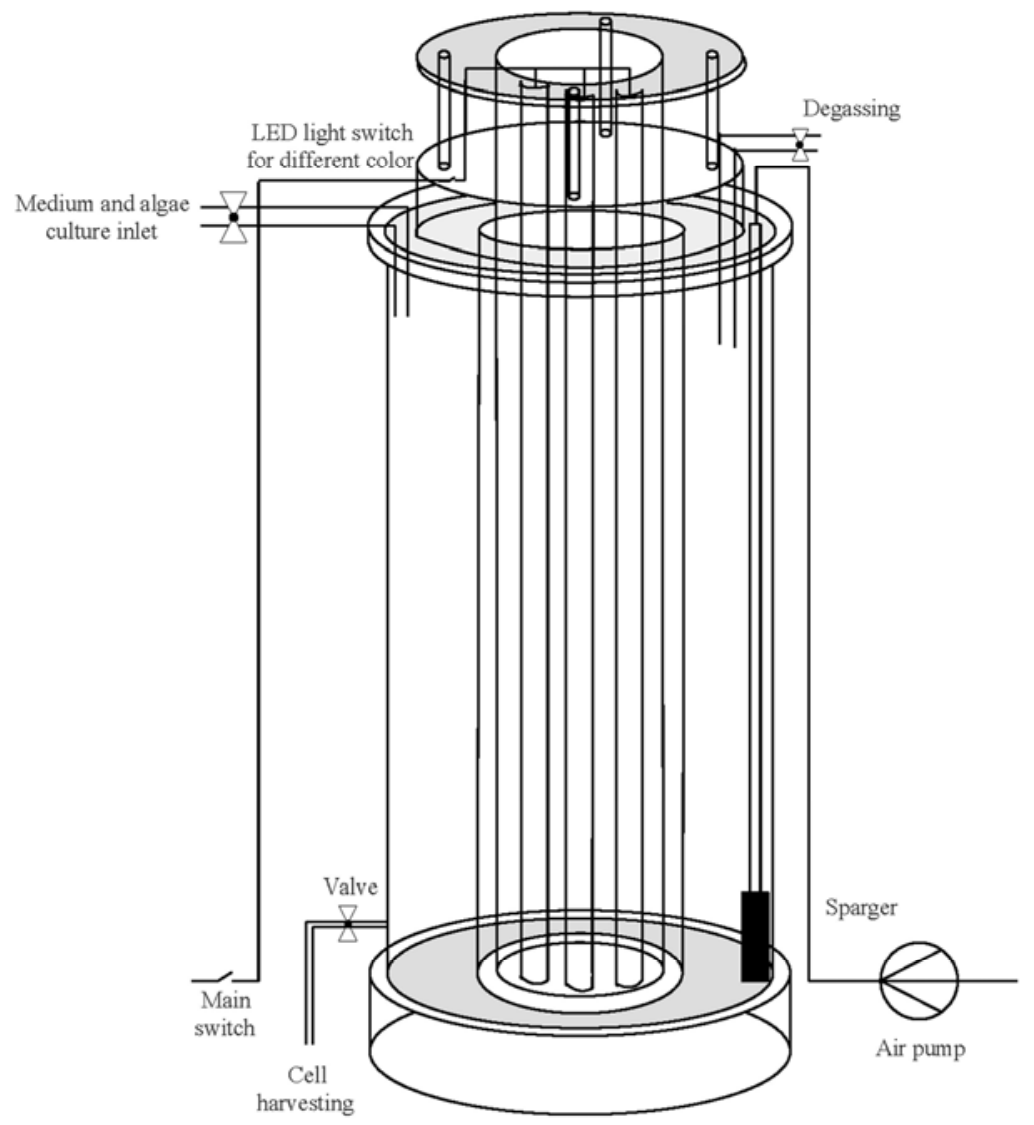

Figure 1. Schematic diagram of the internally-illuminated photobioreactor. 


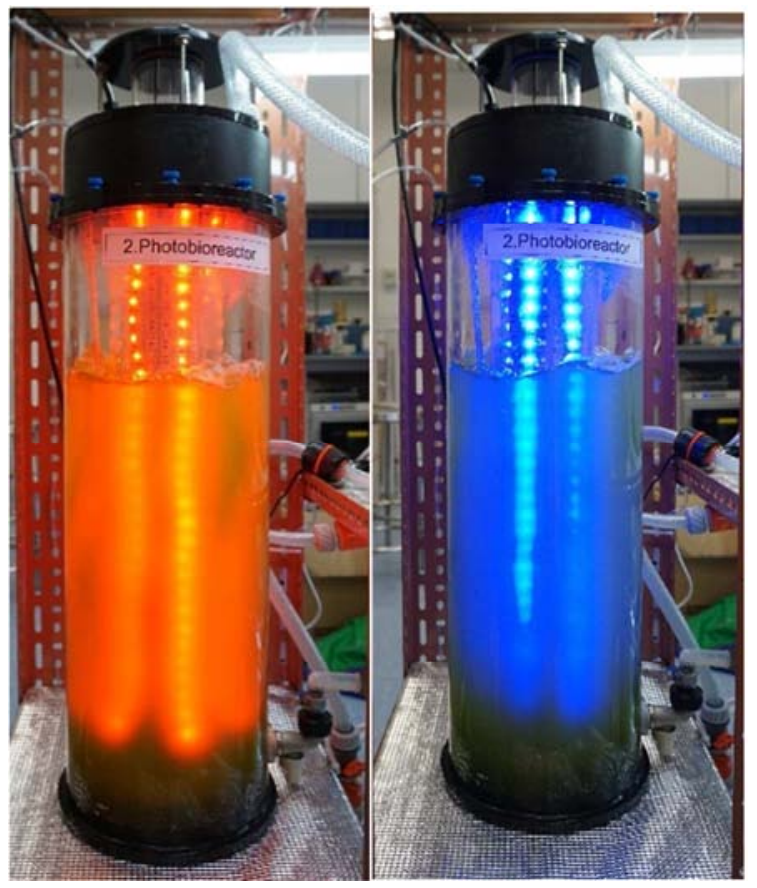

Figure 2. Photograph diagrams of the internally-illuminated photobioreactor under red and blue illuminations.

Photobioreactor design was used with slight adjustment as in Figure 1 and 2 [28-30]. In brief, the dimension of the photobioreactor was $75 \mathrm{~cm}$ (height) $\times 20 \mathrm{~cm}$ (diameter). The reactor wall was made of transparent acrylic plastic with 0.3 $\mathrm{cm}$ thickness. The working volume of the photobioreactor is 13 liters. The photobioreactor received sterilized air at a flow rate of $1.2 \mathrm{~L} / \mathrm{min}$ through an aquarium air pump (V-30, Hailea, China) and a syringe air filter (DISMIC-250CS, 0.45 $\mu \mathrm{m}$, ADVANTEC, Japan). A sparger was located $3 \mathrm{~cm}$ from the bottom of the reactor with a supply of ambient air at 1 $\mathrm{L} / \mathrm{min}$ flow rate. Air and $\mathrm{CO}_{2}$ were supplied to the algal cultures to minimize the sedimentation and adhesion on the inner surface. Three valves were installed on the reactor wall for medium and algal culture inlet, degassing and cell harvesting, respectively. The photobioreactor was equipped with red $(660 \mathrm{~nm})$ and blue $(445 \mathrm{~nm}) 12 \mathrm{~V}$ LED strips as the artificial light sources in the internal column of the photobioreactor. The LED strips provided a homogenous light distribution to the cell culture in the photobioreactor with the characteristics of energy saving, long lifetime and low heat dissipation $[31,32]$. The switchers could adjust the light intensity by turning on/off and the colors of the LED strips. All experiments performed in the photobioreactors were in a temperature-controlled environment at $20 \pm 1{ }^{\circ} \mathrm{C}$ with a black side cover to minimize the disturbance of the environmental light. The light intensity (PAR value, $\mu \mathrm{mol} \mathrm{m} \mathrm{m}^{-2}$ $\mathrm{s}^{-1}$ ) was measured with a light meter (ILT 1400, International Light Technologies, USA). The inoculation for the photobioreactor was conducted by extracting the seed culture and centrifuged at $5000 \mathrm{rpm}$ for $5 \mathrm{~min}$ (14 days culture, linear growth phase). The supernatant was discarded and cells were mixed with 13 L BBM (Cell number: approximately $1 \times 10^{5}$ cells $/ \mathrm{ml}$ ) for the photobioreactor operation. Initial $\mathrm{pH}$ was adjusted to 7 with hydrochloric acid and sodium hydroxide.

\subsection{Experimental Setup}

Batch cultivation of $H$. pluvialis was applied inside the internally-illuminated photobioreactor. Separate light and experimental conditions were provided during the "greenvegetative" and "red-astaxanthin formation" stages. Stage 1: Aim at investigating the vegetative growth stage of $H$. pluvialis with different wavelengths. Stage 2: Aim at optimizing the light intensity for enhancing the cell growth. Stage 3: Aim at investigating the astaxanthin formation. In stage 1 and 2, excess nitrate and phosphate were supplied in $\mathrm{BBM}$ to eliminate the nutrient starvation stress during the vegetative growth stage. In the stage 3 of the astaxanthin formation stage, continuous illumination of blue light (140 $\left.\mu \mathrm{mol} \mathrm{m} \mathrm{m}^{-2} \mathrm{~s}^{-1}\right)$ with modified BBM $(0.025 \mathrm{~g}$ sodium nitrate and phosphate starvation) was applied as oxidative stress. The vegetable growth cells after stage 2 were transferred into starved nitrate and phosphate condition to slow down the cell division and triggered the accumulation of carotenoid. Details of the experimental conditions for the separate stages are listed in Table 1.

Table 1. Experimental stages for the optimization of astaxanthin production.

\begin{tabular}{|c|c|c|c|c|c|c|}
\hline Stage & Aim & Light type & 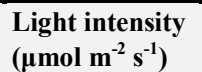 & $\begin{array}{l}\text { Light/dark } \\
\text { cycle }\end{array}$ & $\begin{array}{l}\text { Experiment } \\
\text { time (days) }\end{array}$ & Culture medium \\
\hline 1. & $\begin{array}{l}\text { Investigate the vegetative } \\
\text { growth stage of } H \text {. pluvialis } \\
\text { with different wavelengths }\end{array}$ & $\begin{array}{l}\text { Red }(660 \mathrm{~nm}) \text { and } \\
\text { blue }(445 \mathrm{~nm}) \text { LED } \\
\text { light }\end{array}$ & 70 & $12: 12 \mathrm{~h}$ & 14 & BBM \\
\hline 2. & $\begin{array}{l}\text { Optimize the light intensity for } \\
\text { enhancing the cell growth }\end{array}$ & $\begin{array}{l}\text { Depended on the } \\
\text { result from stage } 1\end{array}$ & $\begin{array}{l}70,140 \text { and } \\
210\end{array}$ & $12: 12 \mathrm{~h}$ & 14 & BBM \\
\hline 3. & $\begin{array}{l}\text { Investigate the astaxanthin } \\
\text { formation }\end{array}$ & $\begin{array}{l}\text { Blue }(445 \mathrm{~nm}) \text { LED } \\
\text { light }\end{array}$ & 140 & $24: 0 \mathrm{~h}$ & 7 & $\begin{array}{l}\text { Modified BBM, adjusted with } 0.025 \mathrm{~g} \\
\mathrm{NaNO}_{3} \text { and phosphorus starvation }\end{array}$ \\
\hline
\end{tabular}

\subsection{Stage 4: Evaluation of Different Extraction Methods on the Astaxanthin Content in H. Pluvialis}

Astaxanthin extraction was all performed with the red encysted cells harvested after stage 3. Photomicrographs were recorded to provide image reference for the extraction performance in selected methods, including the hydrochloric acid digestion, ultrasonication, and microwave with vegetable oil extraction methods. The extracted astaxanthin content ( $\%$ to dry weight) was evaluated with the 
spectrophotometric method.

\subsubsection{Hydrochloric Acid Extraction}

Astaxanthin extracted by hydrochloric acid $(\mathrm{HCl})$ was modified according to the experimental procedures reported by Dong et al. [33] and performed in triplicates. Ten milligrams of the freeze-dried cells were treated with 5-ml 1 $\mathrm{M}, 2 \mathrm{M}$, and $3 \mathrm{M} \mathrm{HCl}$ respectively at $70^{\circ} \mathrm{C}$ water bath for 10 minutes. The resulting solution was cooled and centrifuged at $3500 \mathrm{rpm}$ for $5 \mathrm{~min}$. The supernatants were separated and estimated the amount of extracted astaxanthin. Three replicates were carried out in dim light for light protection and filled with pure nitrogen gas.

\subsubsection{Ultrasonication Extraction}

Ten milligrams of the dried $H$. pluvialis were homogenized in a mortar and pestle [34]. The freeze-dried cells were ultrasounded with $5 \mathrm{ml}$ of distilled water in a $15-\mathrm{ml}$ centrifuge tube by a 130 -watt and $20 \mathrm{kHz}$ ultrasonication processor (VCX130, Sonics and Materials, Inc., Newtown, USA). The extraction time was 5, 10, 15 and 20 minutes. The working cycles consisted of 15 seconds processing time and 15 seconds resting time to avoid overheating. The working amplitude was set to be $35 \%, 45.5$ watts. The centrifuge tubes were placed in an ice bath and performed in dim light during ultrasonication. The sonicated sample was then centrifuged at $5000 \mathrm{rpm}$ for $10 \mathrm{~min}$, and supernatants were extracted and tested for its astaxanthin content.

\subsubsection{Microwave with Vegetable Oil Extraction}

The vegetable oil extraction method was performed in triplicates. Ten milligrams of the freeze-dried cells were stirred and dissolved in acetic acid (5\%) w/v. The microwave assisted extraction was carried out in a microwave oven of frequency $50 \mathrm{~Hz}$ with a maximum power of $400 \mathrm{~W}$ (MWD900, Whirlpool, China) [35, 36]. After treatment, the samples were added to the centrifuge tubes with 5-ml flaxseed oil and olive oil separately [37]. Centrifugation was carried out at $5000 \mathrm{rpm}$ for 5 mins to separate the samples into two layers. The supernatant was examined for astaxanthin content. All experimental steps were carried out in dim light.

\subsection{Analytical Methods}

\subsubsection{Measurement of Cell Number and Algal Biomass}

Cell numbers (cells $/ \mathrm{ml}$ ) were determined with cell counting chambers through a light microscope (Primo Vert, Carl Zeiss, Germany) according to the Standard Method 10200F [38]. Algal biomass was separated by weighted glass fiber filter (type GC-50, $47 \mathrm{~mm}$ diameter, $0.45 \mu \mathrm{m}$, ADVANTEC, Japan) and dried at $105^{\circ} \mathrm{C}$ for 24 hours. The weight difference of the filter paper was measured with an analytical balance (HR-200, A\&D, Japan). The biomass concentration was calculated by the algal dry weight per one liter $(\mathrm{mg} / \mathrm{L})$. The overall specific growth rate $(\mu)$ at the exponential phase was calculated according to:

$$
\mu=\ln \left(x_{2} / x_{1}\right) /\left(t_{2}-t_{1}\right)
$$

Where, $x_{2}$ and $x_{1}$ are the cell dry biomass (cells $/ \mathrm{ml}$ ) at $t_{2}$ and $t_{1}$ (sample day), respectively.

The morphological features (size, number, and color) of $H$. pluvialis cells were observed using a light microscope (Primo Vert, Carl Zeiss, Germany) equipped with a digital camera (Axiocam ERc 5s, Carl Zeiss, Germany).

\subsubsection{Nutrient Content in Growth Medium}

The algal samples were filtered through a glass fiber filter (type GC-50, $47 \mathrm{~mm}$ diameter, $0.45 \mu \mathrm{m}$, ADVANTEC, Japan) and collected with centrifuge tubes. Nitrate concentration $\left(\mathrm{NO}_{3}{ }^{-}-\mathrm{N}\right)$ and phosphorus concentration $\left(\mathrm{PO}_{4}{ }^{3-}-\mathrm{P}\right)$ were measured according to standard methods $[39,40]$ with the use of a UV- spectrophotometer (UV-1800 UV, Shimadzu, Japan).

\subsubsection{Analysis of Total Astaxanthin Content}

The total astaxanthin concentration was accounted for $80 \%$ of total carotene and measured with the wavelength of 450 $\mathrm{nm}$ in UV-spectrometer (UV 1800, Shimadzu, Japan). Both concentrations were calculated according to Huang [41]:

$$
\begin{gathered}
\mathrm{C}_{\mathrm{XC}}=\mathrm{A}_{450} \times 10 / 2500 \times \mathrm{V} / \mathrm{V}_{0} \\
\mathrm{C}_{\mathrm{AX}}=\mathrm{C}_{\mathrm{XC}} \times 80 \%
\end{gathered}
$$

Where $\mathrm{C}_{\mathrm{XC}}$ and $\mathrm{C}_{\mathrm{AX}}$ are the total carotenoid content (mg) and astaxanthin content $(\mathrm{mg})$ respectively; $\mathrm{V}$ and $\mathrm{V}_{0}$ are the extracted and original volume $(\mathrm{mL})$, respectively.

\subsection{Statistical Analysis}

All reported data were collected and expressed as the mean \pm standard deviation $(n=3)$. Statistical analysis was performed using SPSS software (Version 21), tested with ttest, one-way analysis of variance (ANOVA) test and posthoc Tukey's honestly significant difference (HSD) test. The significant level was set at $P<0.05$.

\section{Results and Discussion}

\subsection{Stage 1: Investigation of the Vegetative Growth Stage of H. Pluvialis with Different LED Wavelengths}

Figure 3 shows the exponential growth pattern under red and blue LED light in a photobioreactor. The cell numbers and dry biomass concentration of $H$. pluvialis were significantly higher in red light than in blue light $(P<0.05)$. $H$. pluvialis produced the maximal cell number of $4.58 \pm$ $0.15 \times 10^{5}$ cells $/ \mathrm{ml}$ and dry biomass of $520 \pm 12.5 \mathrm{mg} / \mathrm{L}$ under red light at day 14 (Table 2). The cell number of $H$. pluvialis under red LEDs was nearly $65 \%$ higher than under blue LEDs. The exponential growth phase was observed from day 1 to day 9 , while the stationary phase was observed from day 9 to day 14 under red LEDs. In this stage, almost all $H$. pluvialis cells were kept green under red LEDs. However, approximately $40 \%$ of brown and red encysted cells was observed at day 14 under blue LED illumination. Besides, it was demonstrated that red light induced a higher overall specific growth rate $\left(\mathrm{d}^{-1}: 0.242 \pm 0.004\right)$ than blue 
light $\left(d^{-1}: 0.166 \pm 0.002\right)$. Red light is detected by the photoreceptors which are responsible for the biomass production of $H$. pluvialis [8]. The spectra of $660 \mathrm{~nm}$ matched to the absorption peak of chlorophyll $\mathrm{a}$ and $\mathrm{b}$ which can be absorbed by the photosynthetic organs in $H$. pluvialis [42].

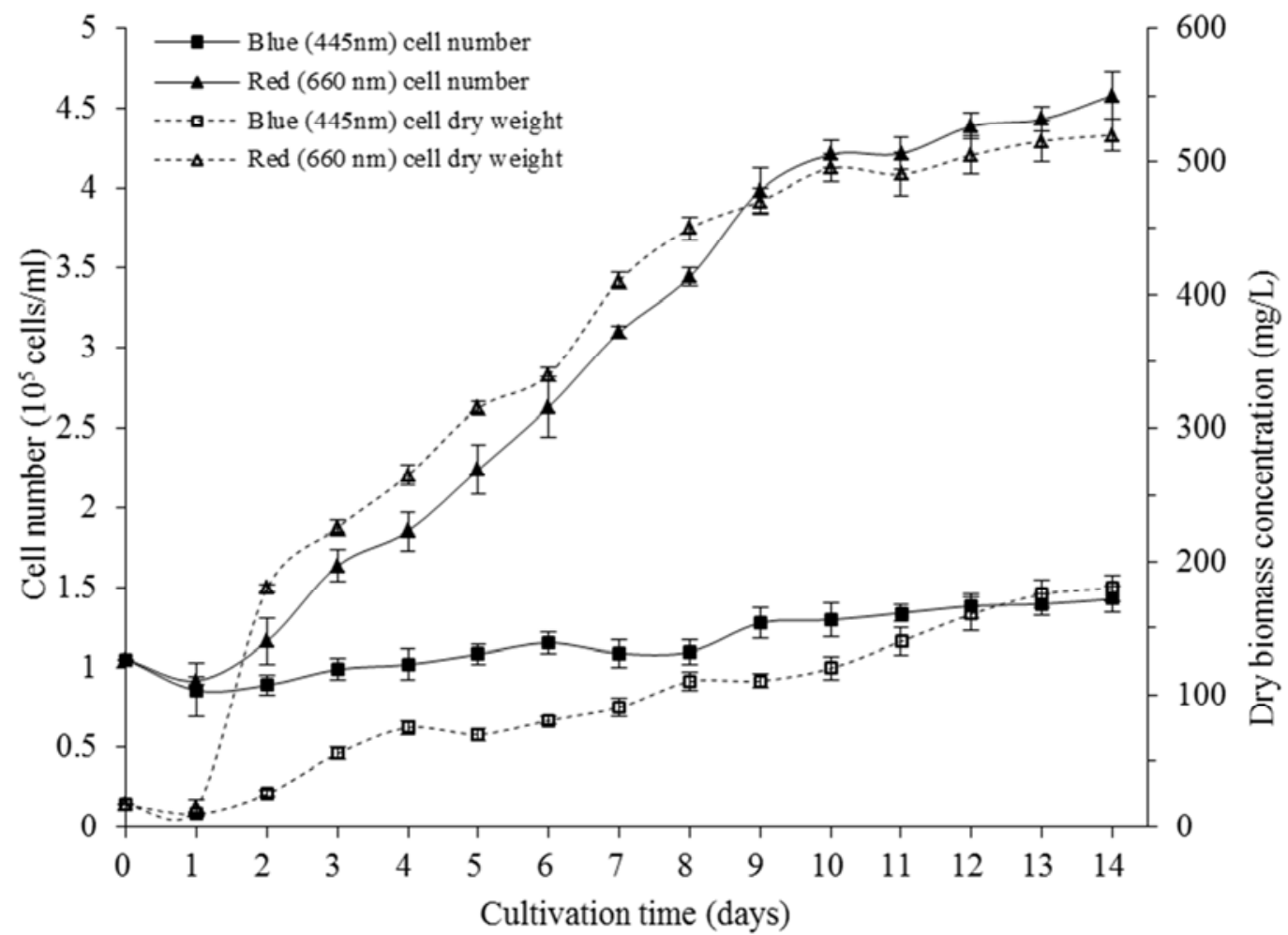

Figure 3. Effect of different wavelength on the cell number and dry biomass concentration of the H. pluvialis culture in photobioreactors. The plotted values indicate mean \pm standard error $(n=3)$.

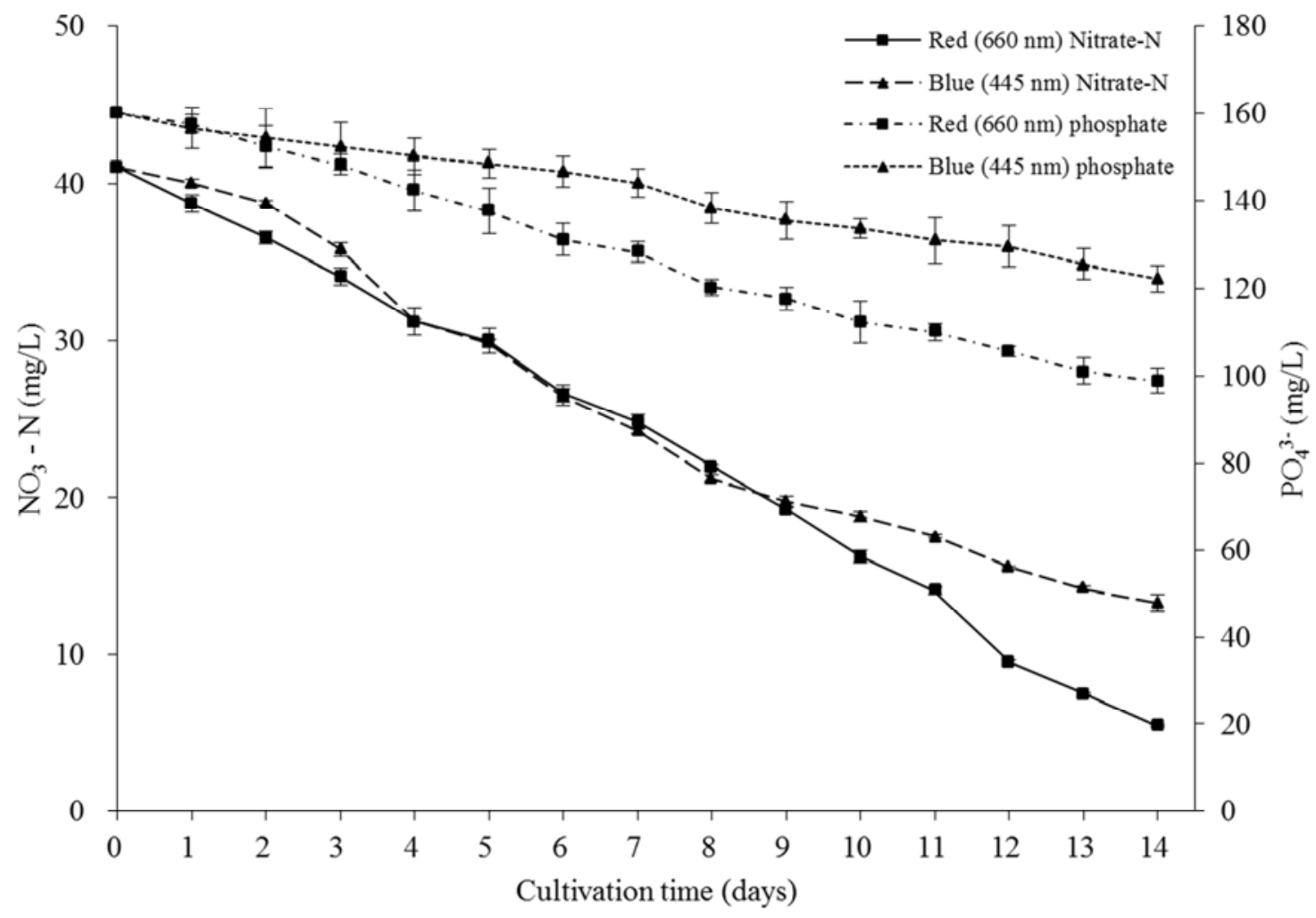

Figure 4. Effect of different wavelength on nitrate and orthophosphate concentration in BBM. The plotted values indicate mean \pm standard error ( $n=3)$. 
Table 2. Initial and final cell number, dry biomass and overall growth specific rate under red and blue LEDs.

\begin{tabular}{|c|c|c|c|c|c|}
\hline $\begin{array}{l}\text { Light color (12:12 } \\
\text { light: dark cycle) }\end{array}$ & $\begin{array}{l}\text { Initial cell numbers } \\
\left(10^{5} \text { cells } / \mathrm{ml}\right)\end{array}$ & $\begin{array}{l}\text { Final cell numbers } \\
\left(10^{5} \text { cells } / \mathrm{ml}\right)\end{array}$ & $\begin{array}{l}\text { Initial dry biomass } \\
\text { (Day 0) (mg/L) }\end{array}$ & $\begin{array}{l}\text { Final dry biomass } \\
\text { (Day 14) (mg/L) }\end{array}$ & $\begin{array}{l}\text { Overall specific } \\
\text { growth rate }\left(d^{-1}\right)\end{array}$ \\
\hline Red LEDs $(660 \mathrm{~nm})$ & 1.06 & $4.58 \pm 0.15^{\mathrm{a}}$ & 17.5 & $520.0 \pm 12.5^{\mathrm{a}}$ & $0.166 \pm 0.002^{\mathrm{a}}$ \\
\hline Blue LEDs (445 nm) & 1.06 & $1.43 \pm 0.08^{\mathrm{b}}$ & 17.5 & $180.0 \pm 9.5^{\mathrm{b}}$ & $0.242 \pm 0.004^{\mathrm{b}}$ \\
\hline
\end{tabular}

Data are given as mean \pm standard deviation $(n=3)$.

Different superscript letters under each column indicate significant difference (t-test, $P<0.05)$ between treatments.

Figure 4 shows the change in nitrate and phosphorus concentration in BBM. The overall specific growth rate of $H$. pluvialis declined (from day 10 to 14 ) under red LEDs. The nitrate nearly used up at day $14(5.43 \pm 0.08 \mathrm{mg} / \mathrm{L})$. Higher biomass production was achieved under red LEDs with a faster nitrate and phosphate removal rate than in blue LEDs.

\subsection{Stage 2: Optimization of the Light Intensity of Red LEDs for the H. Pluvialis Cell Growth}

Enhancing the biomass production of $H$. pluvialis could achieve a high amount of extractable astaxanthin [43]. The biomass growth of $H$. pluvialis was further optimized by red LEDs illumination. Figure 5 shows the growth pattern of $H$. pluvialis under 70,140 and $210 \mu \mathrm{mol} \mathrm{m} \mathrm{m}^{-2} \mathrm{~s}^{-1}$ light intensity under red LEDs. The cell numbers and dry biomass concentration of $H$. pluvialis were significantly influenced by the light intensity of red light $(P<0.05)$. The maximum cell density of $5.31 \pm 0.15 \times 10^{5}$ cells $/ \mathrm{ml}$ and dry biomass of 680 $\pm 10.5 \mathrm{mg} / \mathrm{L}$ were observed under $140 \mu \mathrm{mol} \mathrm{m} \mathrm{m}^{-2} \mathrm{~s}^{-1}$ red LEDs
(Table 3). The stationary phase observed at day 11 was due to the nitrate exhaustion in the culture. After that, the percentage of green cells gently decreased, while the brownish and red encysted cells number increased. Hence, the $70 \mu \mathrm{mol} \mathrm{m} \mathrm{m}^{-2} \mathrm{~s}^{-1}$ intensity became the limiting factor for the growth of $H$. pluvialis. The increase of red LEDs from 70 to $140 \mu \mathrm{mol} \mathrm{m} \mathrm{m}^{-2} \mathrm{~s}^{-1}$ could induce a better biomass production while avoiding the induction of astaxanthin accumulation. However, an increase of intensity to $210 \mu \mathrm{mol} \mathrm{m} \mathrm{m}^{-2} \mathrm{~s}^{-1}$ caused a decline of the cell density at day 12 to 14 and the overall specific growth rate was slower to other two conditions. The

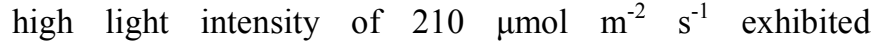
photooxidative stress to $H$. pluvialis, resulting in the formation of astaxanthin and encysted cells [44]. This result showed that the optimized photobioreactor design needs to provide flexible light conditions (illumination cycle, light wavelength and intensity) to assure the biomass and astaxanthin production of $H$. pluvialis.

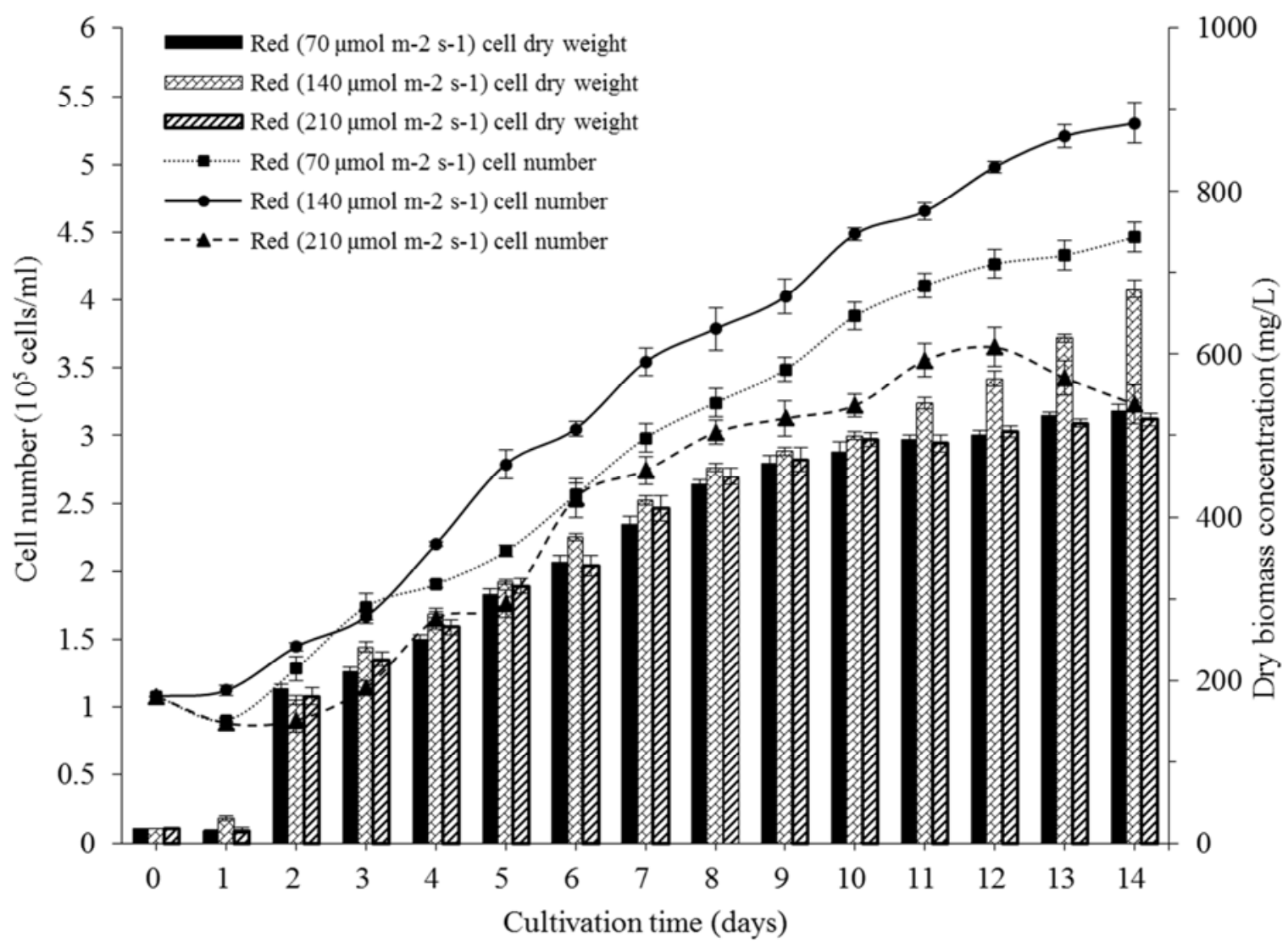

Figure 5. Effects of different red LEDs light intensity on the cell number and dry biomass concentration of the H. pluvialis culture in photobioreactors. The plotted values indicate mean \pm standard error $(n=3)$. 
Table 3. Initial and final cell number, dry biomass and overall growth specific rate under red and blue LEDs.

\begin{tabular}{|c|c|c|c|c|c|}
\hline $\begin{array}{l}\text { Red LEDs light intensity } \\
\text { (12:12 light: dark cycle) }\end{array}$ & $\begin{array}{l}\text { Initial cell numbers } \\
\left(10^{5} \text { cells } / \mathrm{ml}\right)\end{array}$ & $\begin{array}{l}\text { Final cell numbers } \\
\left(10^{5} \text { cells } / \mathrm{ml}\right)\end{array}$ & $\begin{array}{l}\text { Initial dry biomass } \\
\text { (Day 0) (mg/L) }\end{array}$ & $\begin{array}{l}\text { Final dry biomass } \\
\text { (Day 14) (mg/L) }\end{array}$ & $\begin{array}{l}\text { Overall specific } \\
\text { growth rate }\left(d^{-1}\right)\end{array}$ \\
\hline $70 \mu \mathrm{mol} \mathrm{m}{ }^{-2} \mathrm{~s}^{-1}$ & 1.08 & $4.47 \pm 0.11^{\mathrm{a}}$ & 18.0 & $530.5 \pm 8.5^{\mathrm{a}}$ & $0.243 \pm 0.001^{\mathrm{a}}$ \\
\hline $140 \mu \mathrm{mol} \mathrm{m} \mathrm{s}^{-2} \mathrm{~s}^{-1}$ & 1.08 & $5.31 \pm 0.15^{\mathrm{b}}$ & 18.0 & $680 \pm 10.5^{\mathrm{b}}$ & $0.261 \pm 0.001^{\mathrm{b}}$ \\
\hline $210 \mu \mathrm{mol} \mathrm{m} \mathrm{s}^{-2} \mathrm{~s}^{-1}$ & 1.08 & $3.23 \pm 0.14^{\mathrm{c}}$ & 18.0 & $520 \pm 8.0^{\mathrm{a}}$ & $0.241 \pm 0.001^{\mathrm{a}}$ \\
\hline
\end{tabular}

Data are given as mean \pm standard deviation $(n=3)$.

Different superscript letters under a column indicate significant differences $(P<0.05)$ among light intensity treatments, as analyzed by one-way ANOVA, Post-Hoc Test, Turkey HSD.

\subsection{Stage 3: Investigation of the Astaxanthin Formation in H. Pluvialis by Blue LEDs}

In this study, H. pluvialis had been observed to change from green to brownish green at 3 to 4 days and red encysted cells formed at 5 to 7 days (Figure 6 and 7). The blue light stress was adopted and supported a rapid formation of astaxanthin within 7 days.

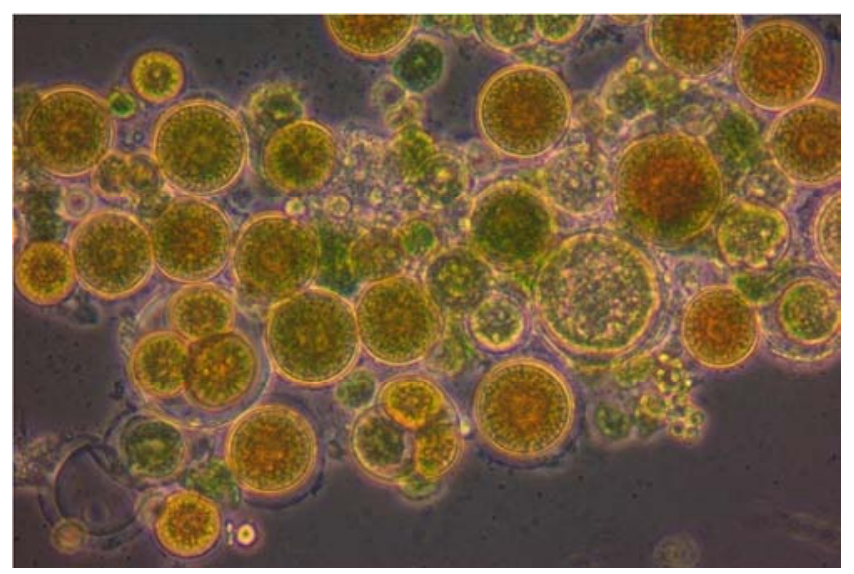

Figure 6. Photomicrographs (400X) of H. pluvialis, change from green to brownish green at 3 to 4 days.

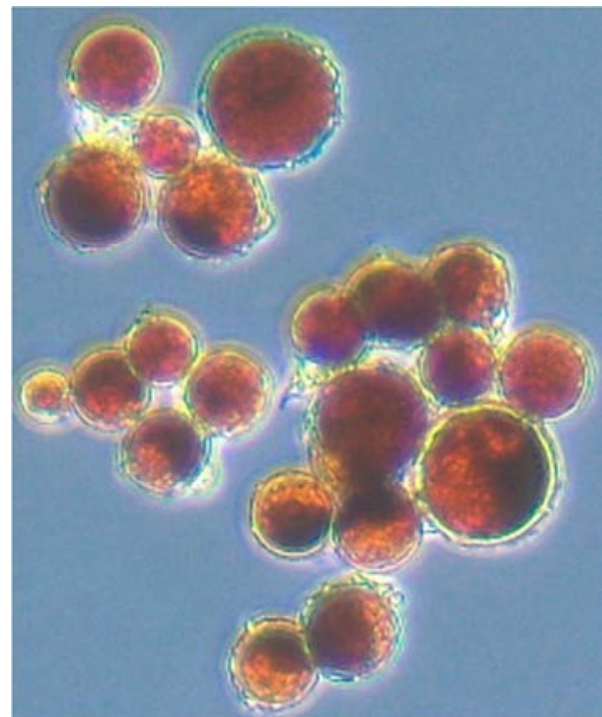

Figure 7. Photomicrographs (400X) of $H$. pluvialis, red encysted cells formed at 5 to 7 days.
In the astaxanthin formation stage, the blue light influenced the gene expression and metabolic pathway of $H$. pluvialis [42]. Such light-harvesting complexes were upregulated in response to blue light via a cryptochromemediated pathway, as cryptochrome is a class of flavoproteins that are sensitive to blue light [45, 46]. The blue photon has a short wavelength and relatively high energy which required by photosynthesis [42]. The blue light wavelength was thus excited and caused photooxidation of the photosystem II and increased the electron flow and carotenogenesis gene expression [8, 47]. Thus, the accumulation of astaxanthin under excessive blue light became the intracellular protective mechanism of the photosynthetic apparatus of $H$. pluvialis [48]. Our findings were in line with Sun et al. [49] that the reactive oxygen species increased at a high level, which was closely related to the environmental stress and induced the astaxanthin formation. Astaxanthin in $H$. pluvialis has become the cell defensive mechanism to oxidative stress $[4,50]$.

\subsection{Morphological Change of H. Pluvialis with the High Light Intensity of Blue LEDs in a Photobioreactor}

Two-stage cultivation strategy was applied in this study for rapid accumulation of the algal biomass, then transferred to high blue light intensity to trigger the transformation of mature cyst $H$. pluvialis cells. The life cycle of $H$. pluvialis consists of macrozooids (or zoospores), green coccoid, microzooids, palmella, and aplanospores (or haematocysts) (Figure 8) [2, 51]. Macrozooids (pear-shape flagellated), green coccoid (non-flagellated), microzooids and palmella are dominant in the "green vegetative" stage, while aplanospores are referred to the "red-astaxanthin formation" stage [5]. In the present experiment, when macrozooids or green coccoid cells were subjected to the high light irradiance of blue LEDs, the cells underwent "encystment." First, the green cells were changed into an intermediate state with brown cells (microzooids, round non-flagellated cells) [47]. Astaxanthin then accumulated in the cell body with loss of flagella and increase in cell size. Finally, the mature red cyst cells were formed to prevail in stressful conditions by accumulating a significant amount of astaxanthin $[52,53]$. 


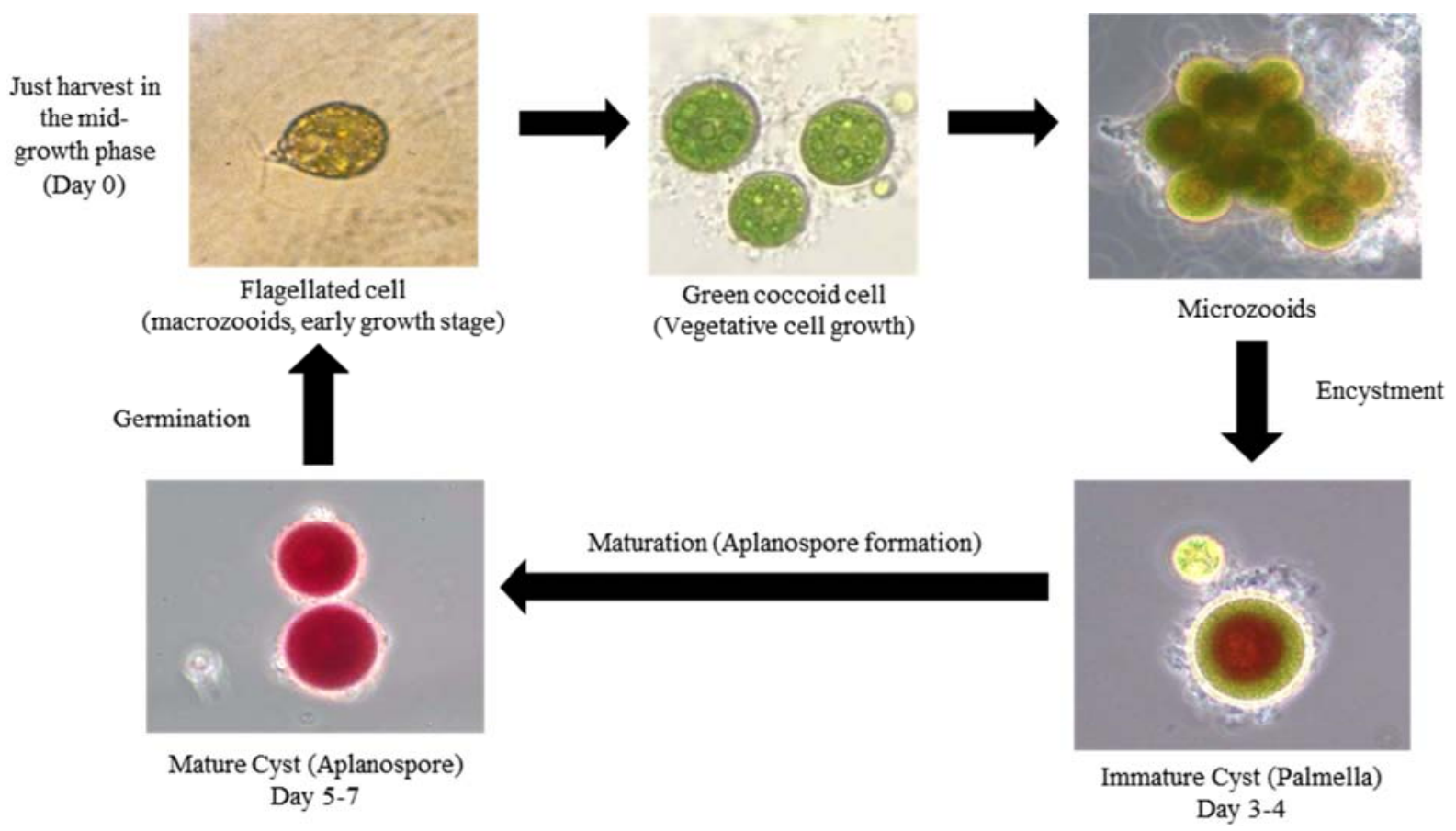

Figure 8. Photomicrograph (400X) of the life cycle of H. pluvialis under blue light experimental conditions.

In this study, the immature encysted cells were found with a larger diameter $(35-52 \mu \mathrm{m})$ when compared to the green coccoid cells $(11-25 \mu \mathrm{m})$ (Figure 9). The result agreed with Kobayashi et al. [54] that in the "red-astaxanthin formation" stage, $H$. pluvialis undergoes cell enlargement with the increasing amount of visual astaxanthin pigment in the cytoplasm. The resting stage of the encysted cells is formed with rigid cell walls [49]. However, H. pluvialis underwent germination under the condition of with fresh BBM, red color of $70-140 \mu \mathrm{mol} \mathrm{m} \mathrm{m}^{-2} \mathrm{~s}^{-1}$. Aplanospores would germinate to form flagellated zoospores again and begin a new vegetative growth cycle [2].

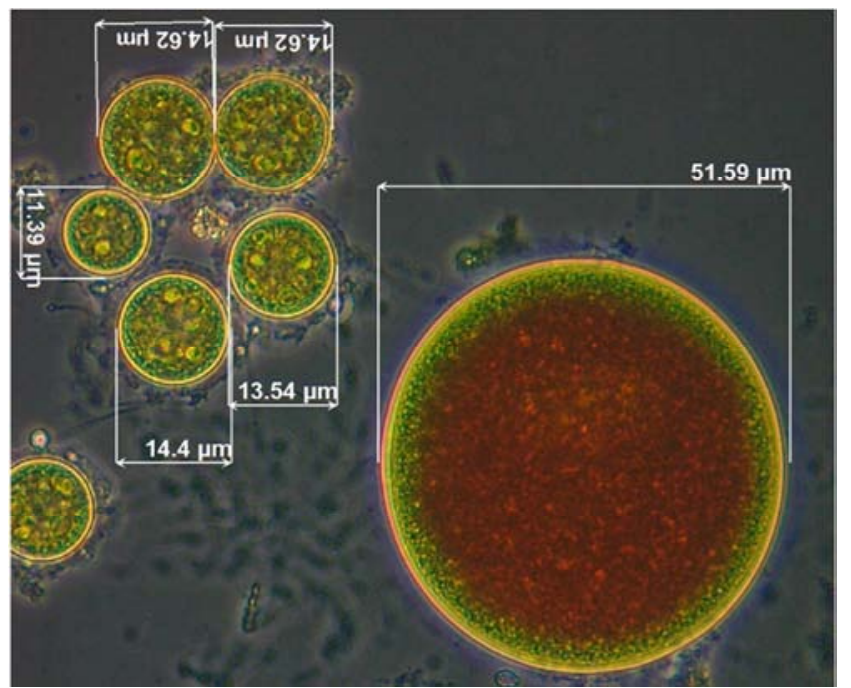

Figure 9. Photomicrographs (400X) of H. pluvialis, green coccoid cell and immature cyst cells.

\subsection{Stage 4: Evaluation of Different Extraction Methods on the Astaxanthin Content in H. Pluvialis}

The presence of a rigid multilayered cell wall in $H$. pluvialis creates the difficulties of astaxanthin extraction, which is cost ineffective [5]. Selecting an appropriate extraction method highly depends on the production scales, cost and final application. However, simple extraction methods, such as using hexane, chloroform and n-hexane solvents, can be toxic, have residue remains, and reduce the nutritional value of the extracted astaxanthin $[55,56]$. Methods based on solvents and/or physical techniques were developed to extract astaxanthin in this study. Three proposed extraction methods were investigated, including the use of (1) acid, (2) ultrasonication, and (3) microwave.

\subsubsection{Acid Extraction Method}

It was observed that $3 \mathrm{M}$ concentration $\mathrm{HCl}$ extraction presented the highest astaxanthin extraction efficiency with $3.85 \pm 0.05 \% \quad$ (Table 4). Figure 10 shows the photomicrograph of the extraction process with encysted $H$. pluvialis, lysing after $\mathrm{HCl}$ acid extraction. Transparent lysed cells were found after treated with $3 \mathrm{M} \mathrm{HCl}$ and centrifugation (Figure 11). Photomicrograph showed that with an increase in the concentration of $\mathrm{HCl}$ acid, the amount of extracted astaxanthin increased (Figure 12). $\mathrm{HCl}$ acid cleaved the vital bond in the cell wall of $H$. pluvialis. However, $4 \mathrm{~N}$ or higher concentration of hydrochloric acid treatment led to astaxanthin ester degradation and morphological changes [34, 57]. 
Table 4. Effects of different concentrations of hydrochloric acid on the extraction of astaxanthin content from H. pluvialis cells.

\begin{tabular}{ll}
\hline Extraction technique & Extracted astaxanthin content (\% to dry weight) \\
\hline 1 M hydrochloric acid & $1.35 \pm 0.02 \%{ }^{\mathrm{b}}$ \\
2 M hydrochloric acid & $1.83 \pm 0.04 \%{ }^{\mathrm{b}}$ \\
$3 \mathrm{M}$ hydrochloric acid & $3.85 \pm 0.05 \%{ }^{\mathrm{a}}$ \\
\hline
\end{tabular}

Data are given as mean \pm standard deviation $(n=3)$.

Different superscript letters indicate significant differences $(P<0.05)$ among $\mathrm{HCl}$ concentrations, as analyzed by one-way ANOVA, Post-Hoc Test, Turkey HSD

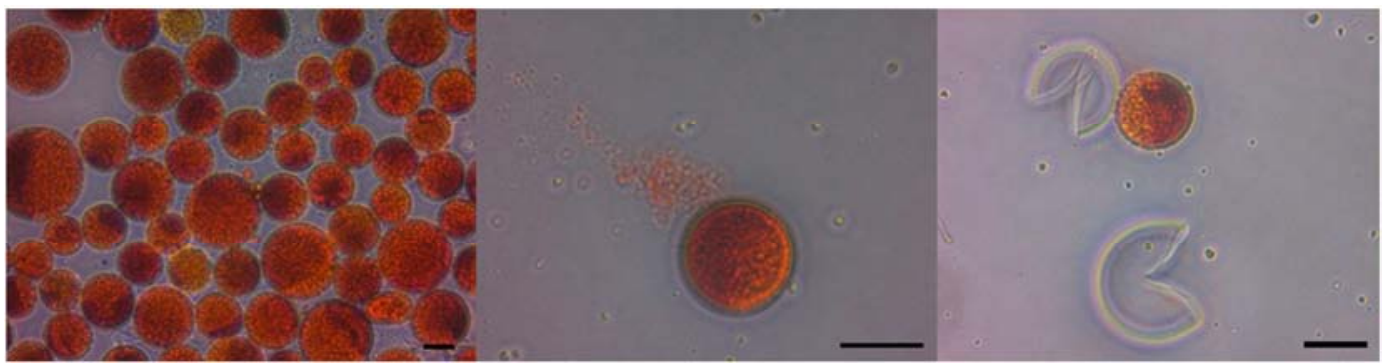

Figure 10. Photomicrographs (400X) of H. pluvialis encysted cells (A) Encysted cells before extraction, (B) Lysing cells (C) After HCl acid extraction. Bar $=$ $30 \mu \mathrm{m}$.
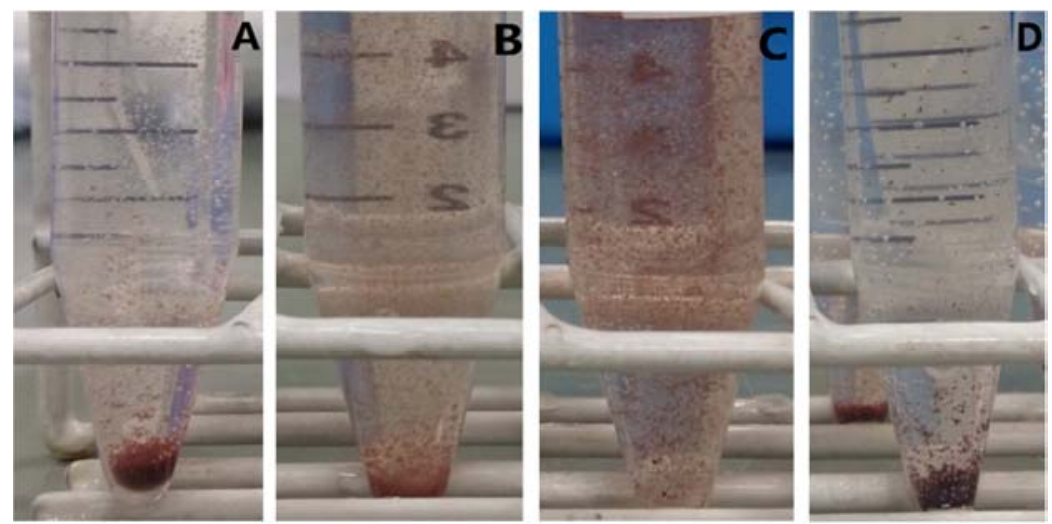

Figure 11. The appearance of H. pluvialis cells that were heat treated for 10 minutes with $5 \mathrm{ml}$ of (A) $1 \mathrm{M}$ hydrochloric acid, (B) $2 \mathrm{M} \mathrm{hydrochloric} \mathrm{acid,} \mathrm{(C)} 3$ $M$ hydrochloric acid, (D) mili- $Q$ water (control).

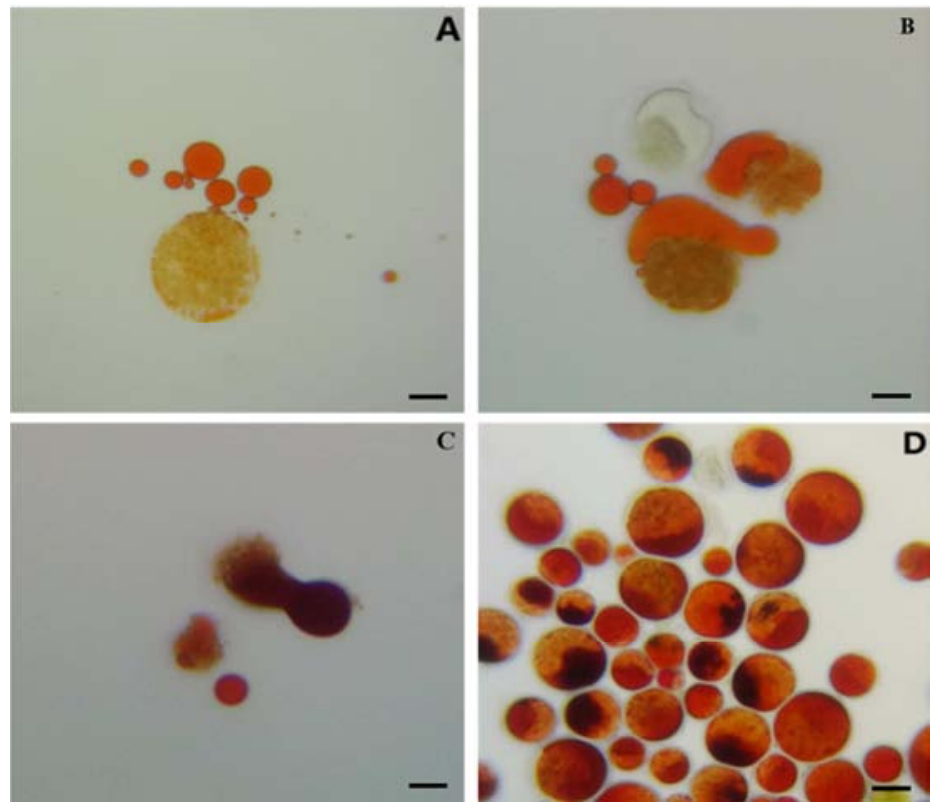

Figure 12. Photomicrographs (400X) of H. pluvialis cells that were heat treated for 10 minutes with $5 \mathrm{ml}$ of (A) $1 \mathrm{M}$ hydrochloric acid, (B) $2 \mathrm{M}$ hydrochloric acid, (C) 3 M hydrochloric acid, (D) Distilled water with encysted cells (control). Bar $=30 \mu \mathrm{m}$. 


\subsubsection{Ultrasonication Extraction Method}

Ultrasonication is beneficial for cell disruption because of the uniform cell destruction by mechanical vibration and acoustic energy [58]. Ultrasonic frequencies in the range of $20-100 \mathrm{kHz}$ are commonly used for mechanical disruption of the cell wall [59]. Figure 13 shows that the appearance of $H$. pluvialis cells before and after ultrasonication. The clear solution was turned into a cherry red color with dark red precipitate after ultrasonication. Ultrasonication disintegrated the cell wall and plasma membrane and astaxanthin was extracted from the intercellular encysted cells (Figure 14). It was observed that the maximum astaxanthin extraction yield was obtained at $2.06 \pm 0.08 \%$ at $15 \mathrm{~min}$ (Table 5). The ultrasonic cell disruption was significantly affected by the initial algal cell concentration and the energy was distributed to each cell [60]. An increase in the sonication time could improve the extraction efficiency but simultaneously would increase the power consumption. However, prolonging the extraction time for more than 15 minutes increased the culture temperature from 50 to $100^{\circ} \mathrm{C}$ and lowered the amount of extracted astaxanthin $[58,61,62]$.
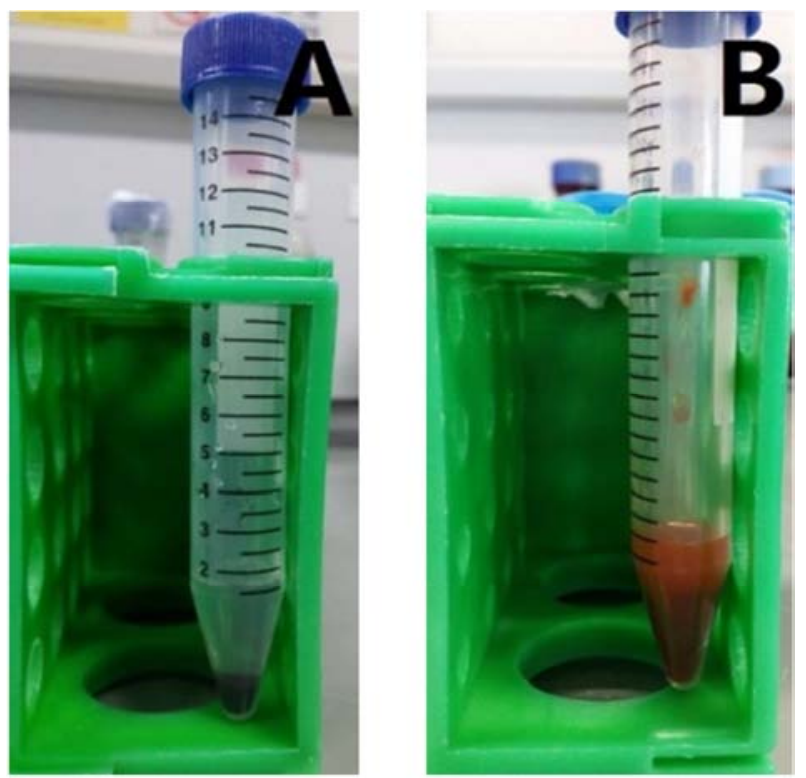

Figure 13. Appearance of H. pluvialis cells (A) Before extraction (B) After 15 minutes ultrasonication.

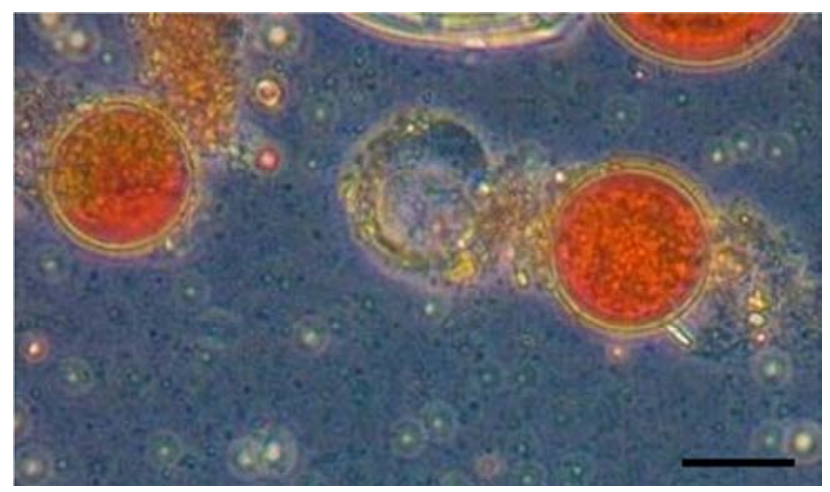

Figure 14. Photomicrograph (400X) of H. pluvialis encysted cells after ultrasonication. Bar $=30 \mu \mathrm{m}$
Table 5. Effects of different ultrasonication operation time on the extraction of astaxanthin content from $\mathrm{H}$. pluvialis cells.

\begin{tabular}{ll}
\hline Extraction technique & $\begin{array}{l}\text { Extracted astaxanthin content (\% to dry } \\
\text { weight) }\end{array}$ \\
\hline 5 minutes ultrasonication & $1.55 \pm 0.04 \%{ }^{\mathrm{a}}$ \\
10 minutes ultrasonication & $1.86 \pm 0.06 \%{ }^{\mathrm{b}}$ \\
15 minutes ultrasonication & $2.06 \pm 0.08 \%^{\mathrm{c}}$ \\
20 minutes ultrasonication & $1.52 \pm 0.04 \%{ }^{\mathrm{a}}$ \\
\hline
\end{tabular}

Data are given as mean \pm standard deviation $(n=3)$.

Different superscript letters indicate significant differences $(P<0.05)$ among ultrasonication time treatments, as analyzed by one-way ANOVA, Post-Hoc Test, Turkey HSD.

\subsubsection{Microwave Extraction Method}

The amount of red astaxanthin pigment extracted by microwave was higher when assisted with flaxseed oil $(0.54$ $\pm 0.01 \%)$ than olive oil $(0.85 \pm 0.02 \%)$ (Table 6$)$. The dry $H$. pluvialis cells were pretreated with $5 \%$ acetic acid. The internal cell temperature was readily increased when $H$. pluvialis were exposed to the high-frequency electromagnetic radiation of microwave. When the water reached its boiling point, $H$. pluvialis cells expanded, resulting in the cell membrane and cell wall disruption (Günerken et al., 2015). The vegetable oil facilitated the recovery of astaxanthin due to its lipophilic characteristics [36, 63]. Figure 15 shows the destruction of cell boundaries of $H$. pluvialis after microwave exposure with flaxseed oil and olive oil treatments. Microwave extraction is a beneficial method to extract biologically active compound without bringing pollution to the environment with a short extraction time [36]. Further investigation would help to apply microwave extraction method in the food industry $[35,63,64]$.

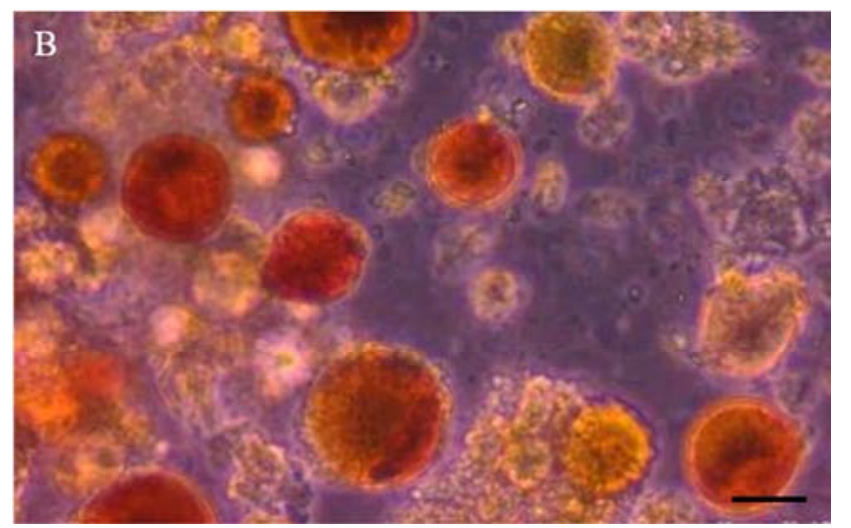

Figure 15. Photomicrographs (400X) of H. pluvialis cells that were treated with acetic acid, microwave assisted and added with $5 \mathrm{ml}$ of (A) Flaxseed oil, (B) Olive oil. Bar $=30 \mu \mathrm{m}$.

Table 6. Effects of different vegetable oils on the extratin of astaxanthin content from $\mathrm{H}$. pluvialis cells.

\begin{tabular}{ll}
\hline Method + Solvent & $\begin{array}{l}\text { Extracted astaxanthin content (\% to dry } \\
\text { weight) }\end{array}$ \\
\hline Microwave + olive oil & $0.54 \pm 0.01 \%^{\mathrm{b}}$ \\
Microwave + flaxseed oil & $0.85 \pm 0.02 \%^{\mathrm{a}}$ \\
\hline
\end{tabular}

Data are given as mean \pm standard deviation $(n=3)$.

Different superscript letters indicate significant differences $(P<0.05)$ between solvent treatments, as analyzed by t-test. 


\section{Conclusions}

In this study, an internally-illuminated photobioreactor was established for $H$. pluvialis cultivation and astaxanthin formation. The experimental results indicated that red LED light was practicable for growing vegetative green cells. Further optimization by increasing the red LED light intensity to $140 \mu \mathrm{mol} \mathrm{m} \mathrm{m}^{-2} \mathrm{~s}^{-1}$ achieved the highest biomass production. The cells were transferred under $140 \mu \mathrm{mol} \mathrm{m} \mathrm{m}^{-2} \mathrm{~s}^{-1}$ blue LEDs together with nitrogen and phosphorus starvation to stimulate the cells encystment and astaxanthin formation. Subsequently, the highest yield of extractable astaxanthin (3.85 $\pm 0.05 \%$ dry weight) was found by treating the cells with $3 \mathrm{M} \mathrm{HCl}$ at $70^{\circ} \mathrm{C}$ water bath for 10 minutes. Based on the current investigation, further studies were conducted on different microalgal strains, so as to enhance the yield of extractable pigments.

\section{Acknowledgements}

The work described in this paper was fully supported by The Open University of Hong Kong, Katie Shu Sui Pui Charitable Trust - Research and Publication Fund (Applied Research), KS2016/2.3. Besides, this work was also supported by a grant from the Research Grants Council of the Hong Kong Special Administrative Region, China (UGC/IDS16/14). We would also like to express our gratitude to the Institute for Research in Innovative Technology and Sustainability (IRITS) of OUHK for their support.

\section{References}

[1] Boussiba, S. (2000). Carotenogenesis in the green alga Haematococcus pluvialis: cellular physiology and stress response. Physiologia Plantarum, 108 (2), 111-117.

[2] Han, D., Li, Y., \& Hu, Q. (2013). Astaxanthin in microalgae: pathways, functions and biotechnological implications. Algae, 28 (2), 131-147.

[3] Hu, J., Nagarajan, D., Zhang, Q., Chang, J. S., \& Lee, D. J. (2017). Heterotrophic cultivation of microalgae for pigment production: A review. Biotechnology advances.

[4] Lemoine, Y., \& Schoefs, B. (2010). Secondary ketocarotenoid astaxanthin biosynthesis in algae: a multifunctional response to stress. Photosynthesis research, 106 (1-2), 155-177.

[5] Shah, M. M. R., Liang, Y., Cheng, J. J., \& Daroch, M. (2016). Astaxanthin-producing green microalga Haematococcus pluvialis: from single cell to high value commercial products. Frontiers in plant science, 7.

[6] Hancock, J. T., Desikan, R., \& Neill, S. J. (2001). Role of reactive oxygen species in cell signalling pathways.

[7] Li, Y., Sommerfeld, M., Chen, F., \& Hu, Q. (2008). Consumption of oxygen by astaxanthin biosynthesis: a protective mechanism against oxidative stress in Haematococcus pluvialis (Chlorophyceae). Journal of plant physiology, 165 (17), 1783-1797.

[8] Lorenz, R. T., \& Cysewski, G. R. (2000). Commercial potential for Haematococcus microalgae as a natural source of astaxanthin. Trends in biotechnology, 18 (4), 160-167.

[9] Mittler, R. (2002). Oxidative stress, antioxidants and stress tolerance. Trends in plant science, 7 (9), 405-410.

[10] Polle, A. (2001). Dissecting the superoxide dismutaseascorbate-glutathione-pathway in chloroplasts by metabolic modeling. Computer simulations as a step towards flux analysis. Plant Physiology, 126 (1), 445-462.

[11] Dose, J., Matsugo, S., Yokokawa, H., Koshida, Y., Okazaki, S., Seidel, U., Eggersdorfer, M., Rimbach, G. \& Esatbeyoglu, T. (2016). Free radical scavenging and cellular antioxidant properties of astaxanthin. International journal of molecular sciences, 17 (1), 103.

[12] Fassett, R. G., \& Coombes, J. S. (2009). Astaxanthin, oxidative stress, inflammation and cardiovascular disease. Future cardiology, 5 (4), 333-342.

[13] Nasri, H., Baradaran, A., Shirzad, H., \& Rafieian-Kopaei, M. (2014). New concepts in nutraceuticals as alternative for pharmaceuticals. International journal of preventive medicine, 5 (12), 1487.

[14] Baker, R. T. M., Pfeiffer, A. M., Schöner, F. J., \& SmithLemmon, L. (2002). Pigmenting efficacy of astaxanthin and canthaxanthin in fresh-water reared Atlantic salmon, Salmo salar. Animal Feed Science and Technology, 99 (1-4), 97-106.

[15] Řehulka, J. (2000). Influence of astaxanthin on growth rate, condition, and some blood indices of rainbow trout, Oncorhynchus mykiss. Aquaculture, 190 (1-2), 27-47.

[16] Guerin, M., Huntley, M. E., \& Olaizola, M. (2003). Haematococcus astaxanthin: applications for human health and nutrition. TRENDS in Biotechnology, 21 (5), 210-216.

[17] Rahman, M. M., Khosravi, S., Chang, K. H., \& Lee, S. M. (2016). Effects of dietary inclusion of astaxanthin on growth, muscle pigmentation and antioxidant capacity of juvenile rainbow trout (Oncorhynchus mykiss). Preventive nutrition and food science, 21 (3), 281.

[18] Song, X., Wang, L., Li, X., Chen, Z., Liang, G., \& Leng, X. (2017). Dietary astaxanthin improved the body pigmentation and antioxidant function, but not the growth of discus fish (Symphysodon spp.). Aquaculture Research, 48 (4), 13591367.

[19] Capelli, B., Bagchi, D., \& Cysewski, G. R. (2013). Synthetic astaxanthin is significantly inferior to algal-based astaxanthin as an antioxidant and may not be suitable as a human nutraceutical supplement. Nutrafoods, 12 (4), 145-152.

[20] Wan, M., Zhang, J., Hou, D., Fan, J., Li, Y., Huang, J., \& Wang, J. (2014). The effect of temperature on cell growth and astaxanthin accumulation of Haematococcus pluvialis during a light-dark cyclic cultivation. Bioresource technology, 167, 276-283.

[21] Chekanov, K. A., \& Solovchenko, A. E. (2015). Possibilities and limitations of non-destructive monitoring of the unicellular green microalgae (Chlorophyta) in the course of balanced growth. Russian journal of plant physiology, 62 (2), 270-278.

[22] Boussiba, S., Bing, W., Yuan, J. P., Zarka, A., \& Chen, F. (1999). Changes in pigments profile in the green alga Haeamtococcus pluvialis exposed to environmental stresses. Biotechnology Letters, 21 (7), 601-604. 
[23] Steinbrenner, J., \& Linden, H. (2001). Regulation of two carotenoid biosynthesis genes coding for phytoene synthase and carotenoid hydroxylase during stress-induced astaxanthin formation in the green alga Haematococcus pluvialis. Plant Physiology, 125 (2), 810-817.

[24] Chen, C. Y., Yeh, K. L., Aisyah, R., Lee, D. J., \& Chang, J. S. (2011). Cultivation, photobioreactor design and harvesting of microalgae for biodiesel production: a critical review. Bioresource technology, 102 (1), 71-81.

[25] Fábregas, J., Otero, A., Maseda, A., \& Domínguez, A. (2001). Two-stage cultures for the production of astaxanthin from Haematococcus pluvialis. Journal of Biotechnology, 89 (1), 65-71.

[26] Ugwu, C. U., Aoyagi, H., \& Uchiyama, H. (2008). Photobioreactors for mass cultivation of algae. Bioresource technology, 99 (10), 4021-4028.

[27] Nichols, H. W., \& Bold, H. C. (1965). Trichosarcina polymorpha gen. et sp. nov. Journal of Phycology.

[28] Wong, Y. K., Ho, K. C. (2015) “Optimization for Cultivation of Microalgae Chlorella vulgaris and Lipid Production in Photobioreactor". The Hong Kong Institute of Engineers, Hong Kong.

[29] Wong, Y. K., Ho, K. C., Tsang, Y. F., Wang, L, Yung, KKL Yung (2016) "Cultivation of Chlorella vulgaris in Column Photobioreactor for Biomass Production and Lipid Accumulation". Water Environment Research 88 (1): 39-45.

[30] Wong, Y. K., Ho, Y. H., Ho, K. C., Leung, H. M., Yung, K. K. L. (2016) Effect of different light sources on algal biomass and lipid production in Internal LEDs-Illuminated Photobioreactor. Journal of Marine Biology and Aquaculture, 2 (2):1-8.

[31] Shu, C. H., Tsai, C. C., Liao, W. H., Chen, K. Y., \& Huang, H. C. (2012). Effects of light quality on the accumulation of oil in a mixed culture of Chlorella $s p$. and Saccharomyces cerevisiae. Journal of chemical technology and biotechnology, 87 (5), 601-607.

[32] Ogbonna, J. C., \& Tanaka, H. (2000). Light requirement and photosynthetic cell cultivation-Development of processes for efficient light utilization in photobioreactors. Journal of applied phycology, 12 (3-5), 207-218.

[33] Dong, S., Huang, Y., Zhang, R., Wang, S., \& Liu, Y. (2014). Four different methods comparison for extraction of astaxanthin from green alga Haematococcus pluvialis. The Scientific World Journal, 2014.

[34] Sarada, R., Vidhyavathi, R., Usha, D., \& Ravishankar, G. A. (2006). An efficient method for extraction of astaxanthin from green alga Haematococcus pluvialis. Journal of agricultural and food chemistry, 54 (20), 7585-7588.

[35] Kang, C. D., \& Sim, S. J. (2008). Direct extraction of astaxanthin from Haematococcus culture using vegetable oils. Biotechnology letters, 30 (3), 441-444.

[36] Zhao, L., Zhao, G., Chen, F., Wang, Z., Wu, J., \& Hu, X. (2006). Different effects of microwave and ultrasound on the stability of (all-E)-astaxanthin. Journal of agricultural and food chemistry, 54 (21), 8346-8351.

[37] Pu, J., Bechtel, P. J., \& Sathivel, S. (2010). Extraction of shrimp astaxanthin with flaxseed oil: effects on lipid oxidation and astaxanthin degradation rates. Biosystems engineering, 107 (4), 364-371.

[38] American Public Health Association, America Water Works. (1995). 10200 F. Phytoplankton Counting Techniques. Washington, DC, USA.

[39] American Public Health Association, America Water Works. (1995b). Standard methods for the examination of water and wastewater. Phosphorus-orthophosphate, PO43-P ascorbic acid method. Washington, DC, USA.

[40] American Public Health Association, America Water Works. (1998). Standard methods for the examination of water and wastewater. NO3- spectrophotometric screening method. Washington, DC, USA.

[41] Huang, S. Y. Studies on Haematococcus Pluvialis Culture Methods and Extraction, Stability and Application of Astaxanthin. (2008)

[42] Schulze, P. S., Barreira, L. A., Pereira, H. G., Perales, J. A., \& Varela, J. C. (2014). Light emitting diodes (LEDs) applied to microalgal production. Trends in biotechnology, 32 (8), 422430 .

[43] Lababpour, A., Hada, K., Shimahara, K., Katsuda, T., \& Katoh, S. (2004). Effects of nutrient supply methods and illumination with blue light emitting diodes (LEDs) on astaxanthin production by Haematococcus pluvialis. Journal of bioscience and bioengineering, 98 (6), 452-456.

[44] Han, D., Wang, J., Sommerfeld, M., \& Hu, Q. (2012). Susceptibility and protective mechanisms of motile and non motile cells of haematococcus pluvialis (chlorophyceae) to photooxidative stress1. Journal of phycology, 48 (3), 693-705.

[45] Gressel, J. (1979). Blue light photoreception. Photochemistry and photobiology, 30 (6), 749-754.

[46] Lepetit, B., \& Dietzel, L. (2015). Light signaling in photosynthetic eukaryotes with 'green'and 'red'chloroplasts. Environmental and Experimental Botany, 114, 30-47.

[47] Saha, S. K., McHugh, E., Hayes, J., Moane, S., Walsh, D., \& Murray, P. (2013). Effect of various stress-regulatory factors on biomass and lipid production in microalga Haematococcus pluvialis. Bioresource technology, 128, 118-124.

[48] Wang, B., Zarka, A., Trebst, A., \& Boussiba, S. (2003). Astaxanthin accumulation in Haematococcus pluvialis (Chlorophyceae) as an active photoprotective process under high irradiance. Journal of Phycology, 39 (6), 1116-1124.

[49] Sun, H., Guan, B., Kong, Q., Geng, Z., \& Wang, N. (2016). Repeated cultivation: non-cell disruption extraction of astaxanthin for Haematococcus pluvialis. Scientific reports, 6 .

[50] Steinbrenner, J. (2006). Regulation der Astaxanthin biosynthese in der Grünalge Haematococcus pluvialis (Doctoral dissertation)

[51] Elliot, A. M. (1934). Morphology and life history of Haematococcus pluvialis. Arch. Protistenk, 82, 250-272.

[52] Boussiba, S., \& Vonshak, A. (1991). Astaxanthin accumulation in the green alga Haematococcus pluvialis. Plant and cell Physiology, 32 (7), 1077-1082.

[53] Li, Y. (2007). The role of carotenogenesis in the response of the green alga Haematococcus pluvialis to oxidative stress. Ph.D. dissertation, The University of Hong Kong, Hong Kong. 
[54] Kobayashi, M., Katsuragi, T., \& Tani, Y. (2001). Enlarged and astaxanthin-accumulating cyst cells of the green alga Haematococcus pluvialis. Journal of bioscience and bioengineering, 92 (6), 565-568.

[55] Crampon, C., Boutin, O., \& Badens, E. (2011). Supercritical carbon dioxide extraction of molecules of interest from microalgae and seaweeds. Industrial \& Engineering Chemistry Research, 50 (15), 8941-8953.

[56] Wu, W., Lu, M., \& Yu, L. (2011). A new environmentally friendly method for astaxanthin extraction from Xanthophyllomyces dendrorhous. European Food Research and Technology, 232 (3), 463-467.

[57] Xiao, A. F., Ni, H., Cai, H. N., Li, L. J., Su, W. J., \& Yang, Q. M. (2009). An improved process for cell disruption and astaxanthin extraction from Phaffia rhodozyma. World Journal of Microbiology and Biotechnology, 25 (11), 2029-2034.

[58] Günerken, E., d'Hondt, E., Eppink, M. H. M., GarciaGonzalez, L., Elst, K., \& Wijffels, R. H. (2015). Cell disruption for microalgae biorefineries. Biotechnology advances, 33 (2), 243-260.

[59] Yamamoto, K., King, P. M., Wu, X., Mason, T. J., \& Joyce, E. M. (2015). Effect of ultrasonic frequency and power on the disruption of algal cells. Ultrasonics sonochemistry, 24, 165171.
[60] Gerde, J. A., Montalbo-Lomboy, M., Yao, L., Grewell, D., \& Wang, T. (2012). Evaluation of microalgae cell disruption by ultrasonic treatment. Bioresource technology, 125, 175-181.

[61] Cuellar - Bermudez, S. P., Aguilar - Hernandez, I., Cardenas - Chavez, D. L., Ornelas - Soto, N., Romero Ogawa, M. A., \& Parra - Saldivar, R. (2015). Extraction and purification of high - value metabolites from microalgae: essential lipids, astaxanthin and phycobiliproteins. Microbial biotechnology, 8 (2), 190-209.

[62] Zou, T. B., Jia, Q., Li, H. W., Wang, C. X., \& Wu, H. F. (2013). Response surface methodology for ultrasound-assisted extraction of astaxanthin from Haematococcus pluvialis. Marine drugs, 11 (5), 1644-1655.

[63] Ambati, R. R., Phang, S. M., Ravi, S., \& Aswathanarayana, R. G. (2014). Astaxanthin: sources, extraction, stability, biological activities and its commercial applications-a review. Marine drugs, 12 (1), 128-152.

[64] Mendes-Pinto, M. M., Raposo, M. F. J., Bowen, J., Young, A. J., \& Morais, R. (2001). Evaluation of different cell disruption processes on encysted cells of Haematococcus pluvialis: effects on astaxanthin recovery and implications for bioavailability. 